\title{
Autologous cell-based therapy for treatment of large bone defects: from bench to bedside
}

\author{
R. Verboket $^{1}$ (I) $\cdot$ M. Leiblein ${ }^{1} \cdot$ C. Seebach ${ }^{1} \cdot$ C. Nau ${ }^{1} \cdot$ M. Janko ${ }^{1} \cdot$ M. Bellen ${ }^{1} \cdot$ H. Bönig ${ }^{2} \cdot$ D. Henrich ${ }^{1} \cdot$ I. Marzi $^{1}$
}

Received: 5 October 2017 / Accepted: 8 January 2018 / Published online: 19 January 2018

(c) The Author(s) 2018. This article is an open access publication

\begin{abstract}
Objectives Reconstruction of long segmental bone defects is demanding for patients and surgeons, and associated with longterm treatment periods and substantial complication rates in addition to high costs. While defects up to $4-5 \mathrm{~cm}$ length might be filled up with autologous bone graft, heterologous bone from cadavers, or artificial bone graft substitutes, current options to reconstruct bone defects greater than $5 \mathrm{~cm}$ consist of either vascularized free bone transfers, the Masquelet technique or the Ilizarov distraction osteogenesis. Alternatively, autologous cell transplantation is an encouraging treatment option for large bone defects as it eliminates problems such as limited autologous bone availability, allogenic bone immunogenicity, and donor-site morbidity, and might be used for stabilizing loose alloplastic implants.

Methods The authors show different cell therapies without expansion in culture, with ex vivo expansion and cell therapy in local bone defects, bone healing and osteonecrosis. Different kinds of cells and scaffolds investigated in our group as well as in vivo transfer studies and BMC used in clinical phase I and IIa clinical trials of our group are shown.

Results Our research history demonstrated the great potential of various stem cell species to support bone defect healing. It was clearly shown that the combination of different cell types is superior to approaches using single cell types. We further demonstrate that it is feasible to translate preclinically developed protocols from in vitro to in vivo experiments and follow positive convincing results into a clinical setting to use autologous stem cells to support bone healing.
\end{abstract}

Keywords Bone defect $\cdot$ Cell therapy $\cdot$ Stem cells $\cdot$ BMC $\cdot$ Bone marrow mononuclear cells $\cdot$ Regeneration

\section{Background}

Reconstruction of long segmental bone defects is demanding for patients and surgeons, and associated with longterm treatment periods and substantial complication rates in addition to high costs. Large bone defects result from major trauma, surgical excision of tumors, debridement after posttraumatic septic non-unions, osteitis or explantation of endoprothesis. While defects up to $4-5 \mathrm{~cm}$ length might

I. Marzi

marzi@trauma.uni-frankfurt.de

R. Verboket

Rene.Verboket@kgu.de

1 Department of Trauma-, Hand- and Reconstructive Surgery, University Hospital Frankfurt, Frankfurt, Germany

2 Department of Transfusion Medicine and Immune Hematology, University Hospital Frankfurt and DRK Blood Donor Service Baden-Württemberg-Hessen, Frankfurt, Germany be filled up with autologous bone graft, heterologous bone from cadavers, or artificial bone graft substitutes, current options to reconstruct bone defects greater than $5 \mathrm{~cm}$ consist of either vascularized free bone transfers, the Masquelet technique or the Ilizarov distraction osteogenesis [1-3].

Alternatively, autologous cell transplantation is an encouraging treatment option for large bone defects as it eliminates problems such as limited autologous bone availability, allogenic bone immunogenicity, and donor-site morbidity, and might be used for stabilizing loose alloplastic implants $[4,5]$. Until now, systematic clinical studies applying autologous bone cell transplantation have barely performed.

In contrast to the extensive in vitro and animal experiment data, there are only few studies that show clinical results for cell therapy treatments to regenerate bone.

There are two clinical application forms of cell therapies to regenerate bone. Besides the biological differences, various health law-related consequences also emerge for the manufacturer and the orthopedic surgeon in attendance. 
1. Cell therapies without expansion in culture

2. Cell therapies with ex vivo expansion

\section{Cell therapies without expansion in culture}

Cells are harvested or produced during an operation. Bone marrow aspiration concentrate (BMAC) is a typical example of this form of application. At the beginning of the operation, a defined volume of bone marrow is harvested by vacuum aspiration of the ventral or dorsal iliac crest and suspended in an anti-coagulating heparin and anticoagulant citrate dextrose solution in a transfusion bag. Mononuclear cells are then isolated from the harvested bone marrow aspirate in a density gradient centrifuge in the closed system that has been used since 2005 .

In a prospective clinical study and in various experimental treatments, the research group of Jäger et al., has successfully treated over 100 patients with local bonehealing disorders using a BMAC biomaterial composite [6]. Fifty percent of the bone defects were grafted with autologous cancellous bone and the remaining $50 \%$ with a BMAC biomaterial composite (hydroxylapatite, Orthoss ${ }^{\circledR}$, Geistlich, Wolhusen, Switzerland versus collagen sponge, Gelaspon ${ }^{\circledR}$, Chauvin Ankerpharm, Berlin, Germany). So far, the study has found that the use of BMAC reduces the harvest of autogenous bone by $50 \%$ with no slowing down or absence of bone healing being observed [7, 8]. No complications with the application were observed in any of the patients. The low complication risk of this procedure [9] and the osteogenic potency in the parallel application of different biomaterials has also been reported by other research groups $[10,11]$. However, a confirmatory clinical study under the current regulatory requirements has not been reported to our knowledge.

\section{Cell therapies with ex vivo expansion}

In orthopedics and traumatology, autologous cell therapies have been used regularly on the musculoskeletal system after ex vivo cultivation, at least since the clinical introduction of autologous chondrocyte transplantation (ACI). Unlike cartilage regeneration, for which ACI was used in more than 12,000 patients between 1987 and 2005, [12, 13] there are no reliable data on osseous regeneration after temporary in vitro cultivation. In the treatment of necrosis of the femoral head, for instance, whereas numerous one-step transplantations are documented, only three case studies with a maximal observation period of 3 months can be found. Here, a mixed cell population from bone marrow cells (so-called tissue repair cells, TRCs) was expanded over 12 days under GMP conditions and then transplanted autologously together with a scaffold made of tricalcium phosphate (TCP) within the framework of core decompression [14].

A new started study with ex vivo expanded mesenchymal stromal cells (hBM- MSCs) is the Orthounion study. This study is a multi-centre, open, comparative, three-arm, randomized clinical trial (EudraCT-No. 2015-00043132 ) to compare the efficacy of autologous human bone marrow-derived expanded mesenchymal stromal cells treatments versus iliac crest autografts. Bone healing in patients with diaphyseal and/or metaphysodiaphyseal fractures, atrophic or oligotrophic non-union is investigated. The project started on 1st January 2017.

The particular drawbacks of temporary cultivation of MSCs lie not only in the considerable logistical effort to ensure the quality of the cell therapy treatment but especially in the biological characteristics of this cell population. As soon as MSCs are isolated from their tissue mass and transferred to a culture dish, differentiation proceeds in accordance with the culture conditions [15-17]. The yet inconclusive biological effects when fetal bovine serum is used in the culture, as well as telomere shortening, and thus cell aging with ex vivo cultivation also have to be considered. Furthermore, analysis of 170 neoplasia-associated DNA promoters was able to show that despite the relatively high genetic stability of MSCs from human bone marrow or adipose tissue, damage in the genome could occur at later stages [18]. The question as to whether these genotoxic effects of prolonged in vitro cultivation are also clinically manifested after re-transplantation remains unanswered, however. The potential effects of changes in the chromatin structure due to epigenetic factors at the beginning of osteoblastic differentiation also remain largely unknown [19].

\section{Cell therapy in local bone defects, bone healing disorders and osteonecrosis}

Other research groups have also reported positive clinical results after using human bone marrow cells. Giannini et al. showed that in patients with osteochondral defects in the talus, functional improvements were achieved through autologous bone marrow cell transplantation by arthroscopic surgery [20]. As early as 1991, Conolly et al. [21] reported equivalent healing rates for autologous bone marrow grafting to treat post-traumatic pseudarthrosis of the tibia. Other authors also support the high osseous regeneration potency of the percutaneous implantation of autologous bone marrow concentrate to treat pseudarthrosis $[22,23]$ and discuss supplementary osteoblastic stimulation using platelet-rich plasma (PRP) [21].

Although the underlying mechanism for the regeneration process is not completely understood, essentials constitutes have been assumed besides biomechanical stability and vascularization in accelerating new bone formation: growth 
factors, osteoprogenitor cells and extracellular matrix/natural scaffolds.

An overview about published studies after cell therapy in bone defects or bone healing disorders are summarized in Table 1.

The substantial requirements of bone healing are summarized by Giannoudis et al. in the diamond concept of bone fracture healing. That concept considered the mechanical environment, osteogenic cells, vascularity, osteoconductive scaffolds and growth factors [24] as essential factors for successful tissue engineering-based bone healing approaches. In line with that concept, Drosse et al. discussed a multi-component approach for tissue engineering of bone defects ranging from cell-based to scaffold-based approaches also including the use of osteogenic growth factors and genetic engineering [25].

As a basis for bone healing, therefore, mechanical stability, osteoconductive scaffolds, and a sufficient vascular bed are the basis for bone healing [24]. The role of growth factors is important as well, but one can assume that viable cells and vascularization allow the secretion of relevant factors, but it is unclear if this is sufficient. Better results in healing have been shown by application of growth factors [26, 27]. Thus, the addition of stem cells to a bone defect filled up with scaffolds in a vascularized environment appears to be a prospective, but challenging aim.

Considering these aspects, we started to investigate essential components obligatory for bone tissue engineering to develop a clinically applicable protocol for (stem)cell-based treatment of bone defects. The aim of this review is to trace back our research in this field from initial experiments to isolate and characterize stem cell populations, to evaluate suitable biomaterials in vitro, to proof the effect of regenerative cells and biomaterials in vivo, and based on that, to apply for and conduct first clinical trials to assess safety, feasibility (phase I) and the effect (phase IIa) of autologous bone marrow mononuclear cells (BMC) transplanted into the defect site on the bone healing (Fig. 1). All over, it took about 10 years to come from cell culture into humans and clinical trials are now ongoing.

\section{Cells}

We followed the hypothesis that the combination of cells with complement properties might be more effective for the bone defect healing compared to approaches using single cell sorts. Endothelial progenitor cells (EPC) as potentially proangiogenic acting cells as well as marrow stromal cells (MSC) capable of forming new bone tissue were selected. A short overview on the biology of both cell types will be provided in the following. In this regard bone marrow mononuclear cells (BMC), as being a mixture of different cell types, are also worth to be mentioned.

\section{Endothelial progenitor cells (EPC)}

At least two major types of endothelial cell lines can be obtained by in vitro culture of mononuclear cells; first, the so-called "endothelial-like cells" or "early EPC" and second, the so-called "outgrowth EPC" or "late EPC". Early EPC were used in all of our experimental projects. These cells are supposably derived from monocytic/dendritic cells co-expressing some endothelial markers together with leukocyte markers and demonstrating a high VEGF synthesis, some investigators hence designate them as endothelial-like differentiated PBMC $[28,29]$. In the following 'early EPC' will be referred to as EPC. These cells can be generated in a sufficient amount within 3-5 days from a tenable volume of blood [30]. The contribution of early EPC in forming blood vessels is a matter of debate. Crosby and colleagues have reported that $8.3-11.2 \%$ of endothelial cells which developed in sponge-induced granulation tissue over 1 month were derived from circulating hematopoietic progenitor cells [31]. So it has been proposed that early EPC more likely act in a paracrine manner, secreting proangiogenic factors such as VEGF [28]. Own previous work indicated that early EPC are activated after multiple trauma by increased VEGF and TGF- $\beta$ [32] but are harmed by increased concentrations of TNF- $\alpha$, IL-1 $\beta$ [33] and activated neutrophils [34].

In contrast, outgrowth EPC or late EPC are characterized by a broad spectrum of endothelial markers including VEGF-R2 and UEA-I-Lectin. They express CD34, lack myeloid markers (CD45) and can be expanded in vitro. It is likely that these cells are generated from bone marrowderived CD133 + cells [35, 36]. The culture period of late EPC is much longer, compared to that of early EPC. Single colonies of late EPC appear after 3-4 weeks [37], whereas early EPC require only $3-5$ days $[38,39]$. We observed that late EPC were also activated by musculoskeletal trauma [40], and that migration of late EPC towards injured tissue is impaired in elderly patients probably due to a reduced capability for VEGF synthesis [41].

\section{Marrow stromal cells (MSC)}

MSC were primarily described by Friedenstein et al. [42] as plastic-adherent cells or colony forming unit fibroblasts based on their adherence to tissue culture surfaces. MSC own a high proliferative potential and are phenotypically characterized by surface expression of CD71, CD73, CD90 and CD105, and the absence of the leukocyte marker CD45 or markers expressed by hematopoietic stem cells such as CD34 [43]. These cells can be functionally characterized by their potential for trilineage differentiation towards the 


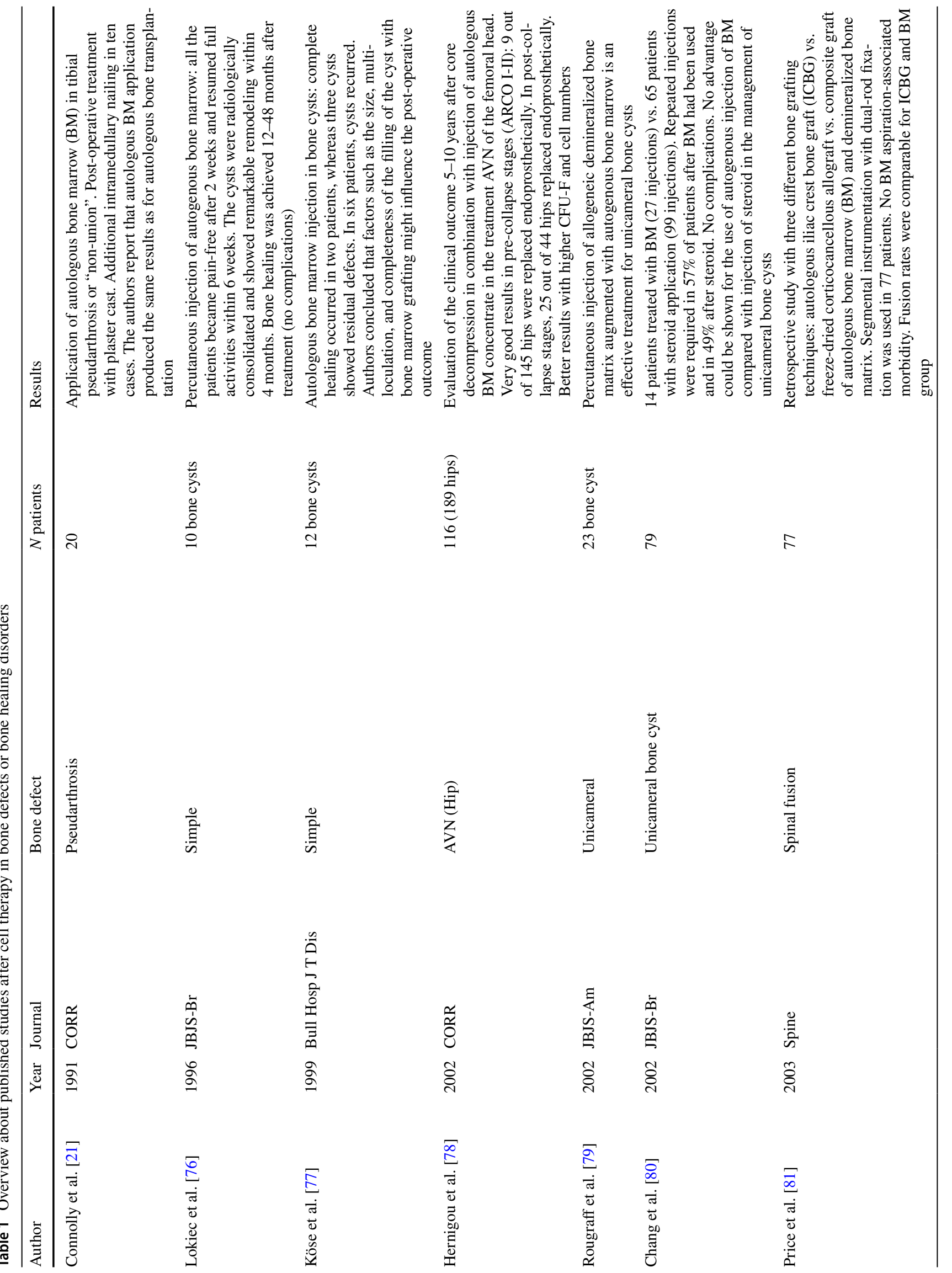




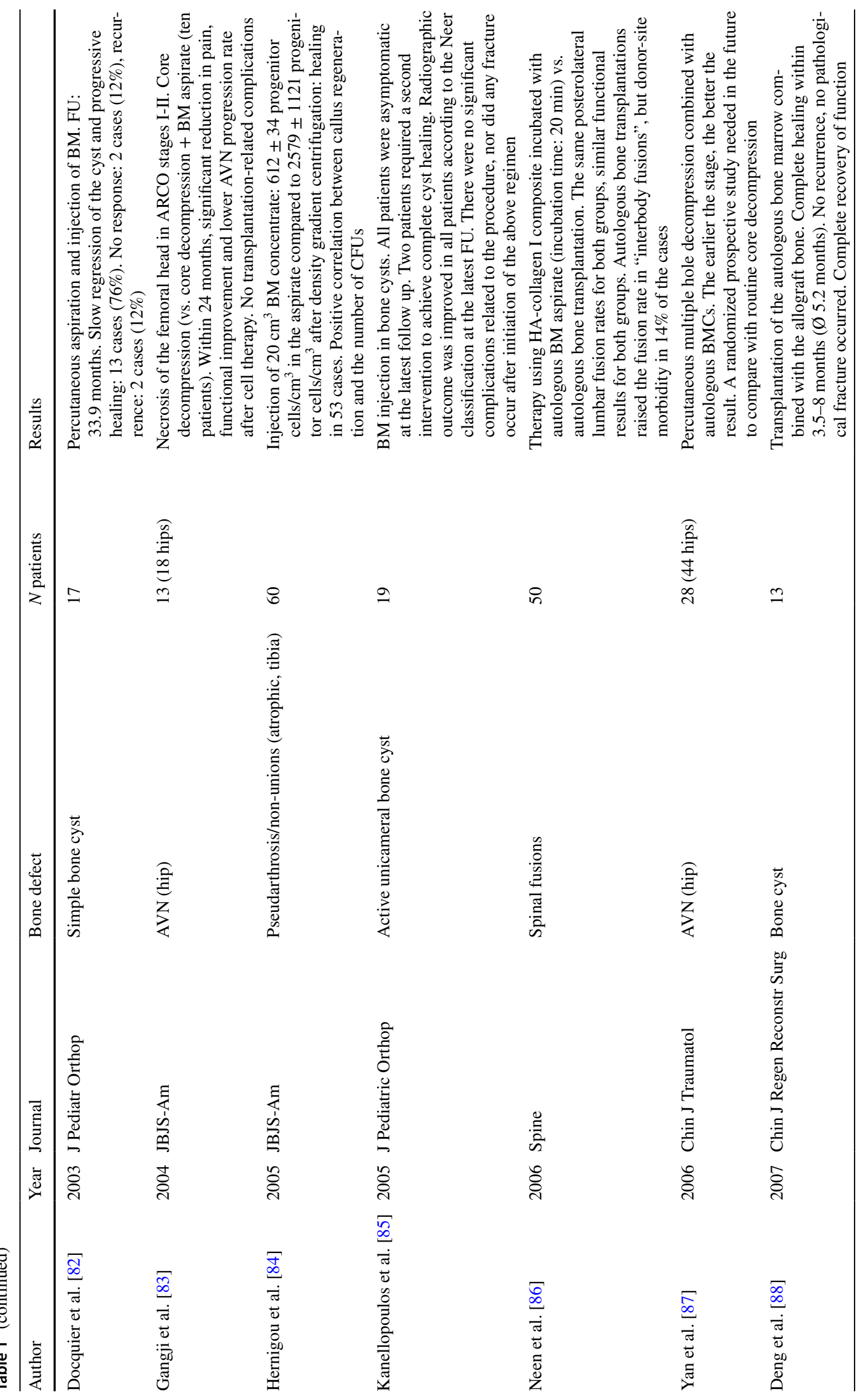




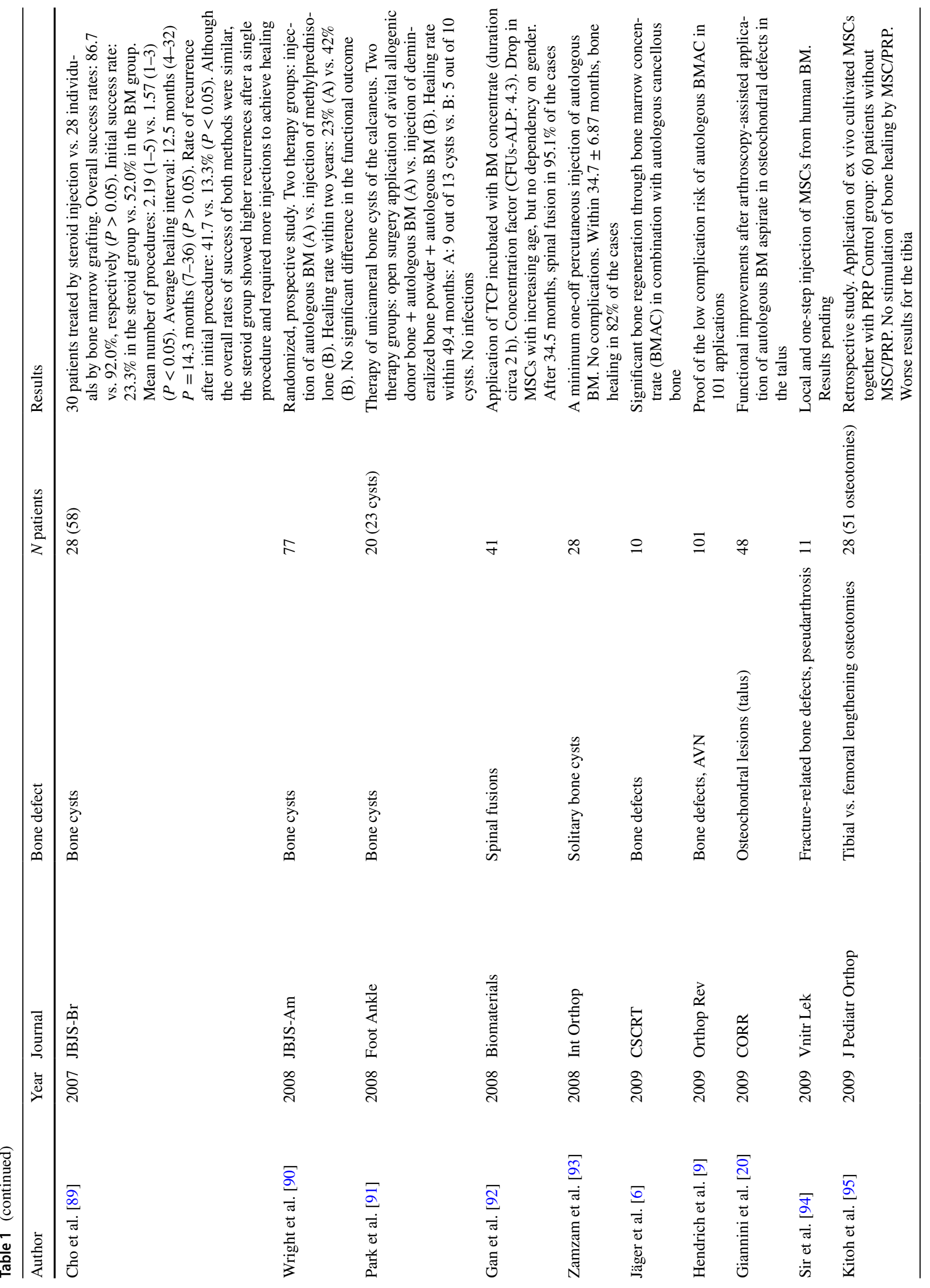




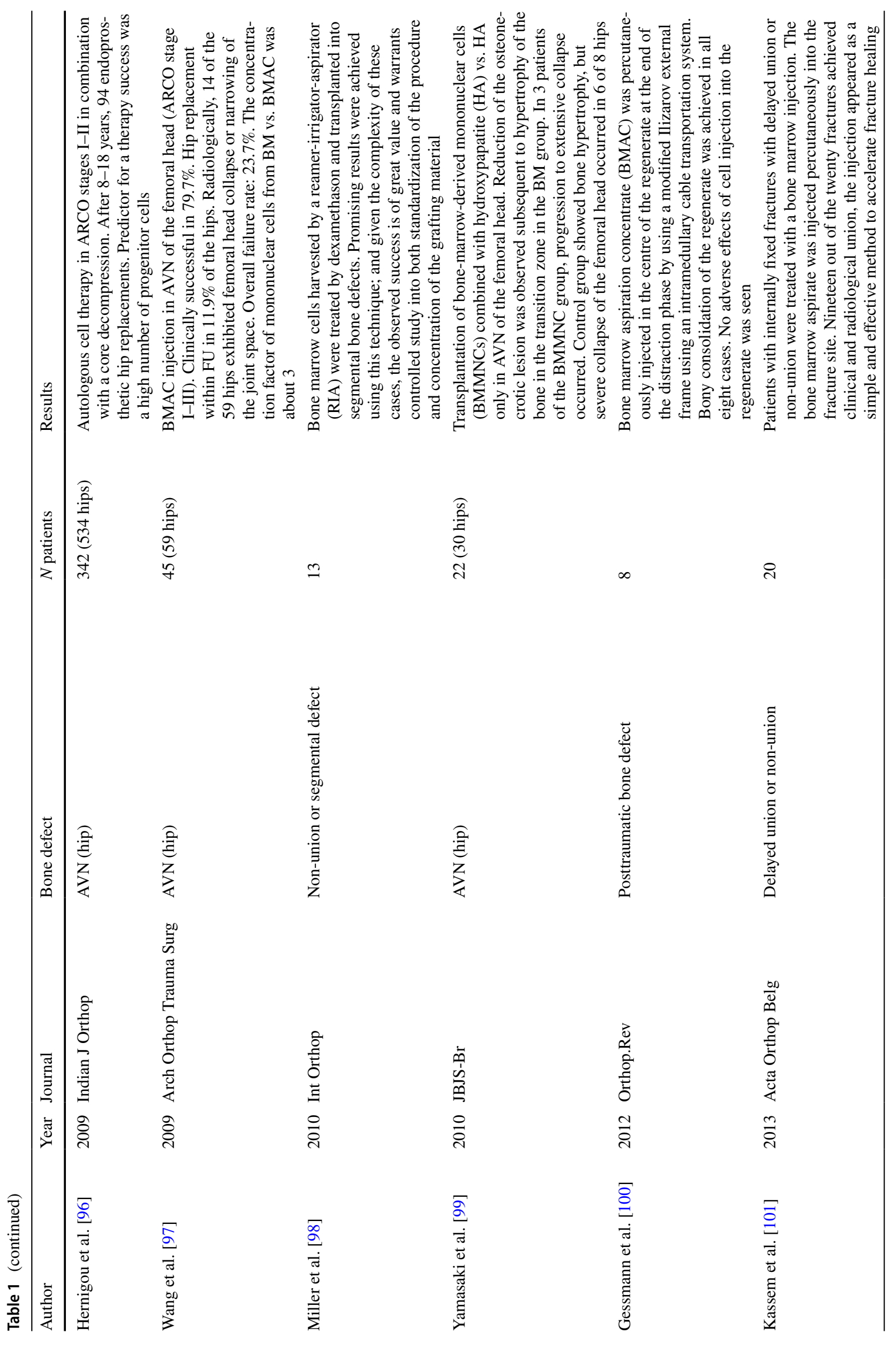




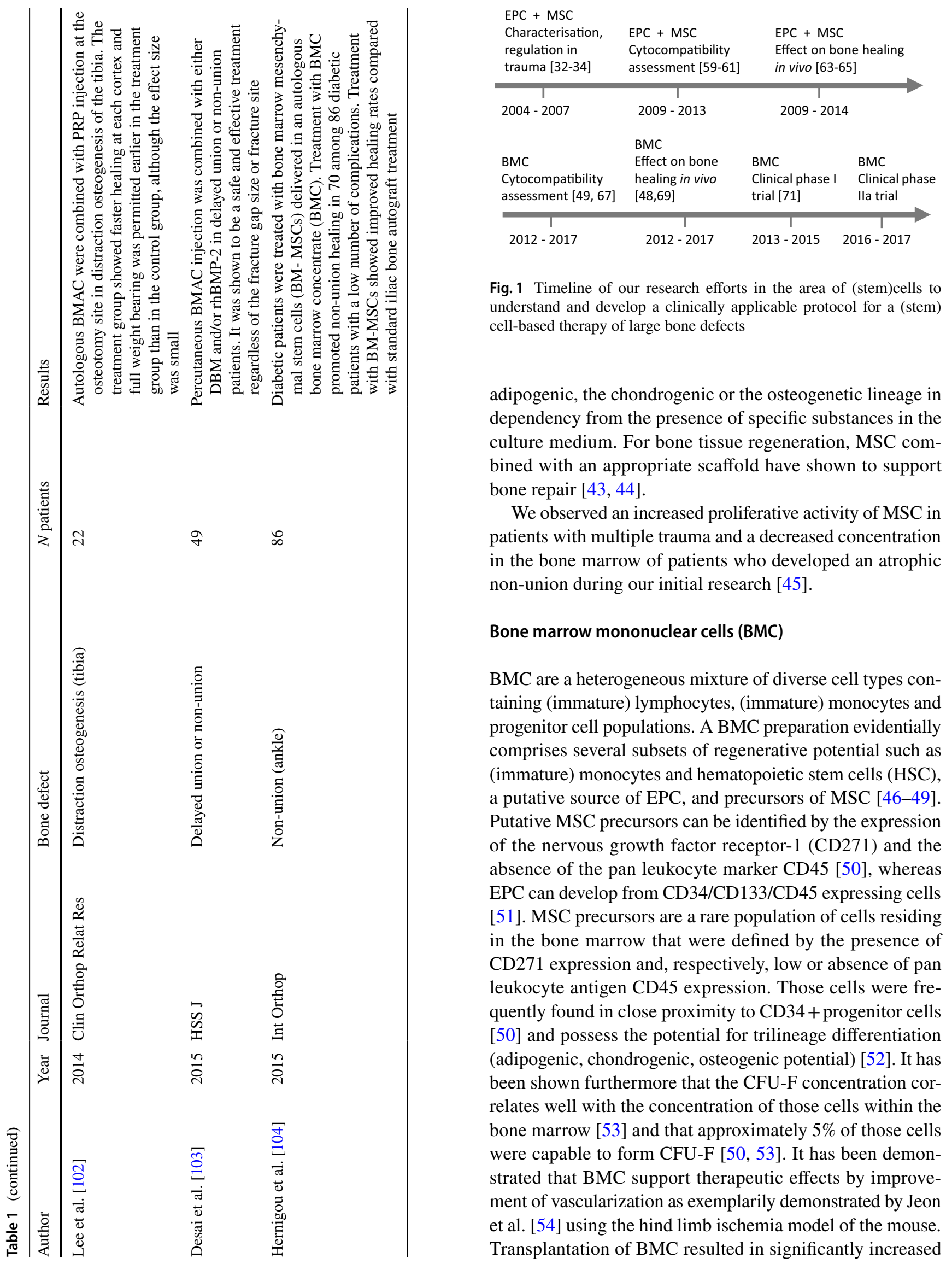


microvessel density [54]. Interestingly, in cardio-vascular cell transplantation studies, BMCs were mostly applied in large successful studies (Assmus et al.) [46]. BMCs are easily taken by bone marrow aspiration of the iliac crest and processed for further clinical use. The different cells with regenerative potential are shown in Fig. 2.

\section{Cells sources}

Stem cells for bone tissue engineering can be harvested from different sources. Human MSC and EPC can be obtained not only from iliac crest bone marrow but can also be isolated from marrow of the femur using a Reamer Irrigator Aspirator (RIA). The application of a Reamer/Irrigator/Aspirator (RIA) system allows the harvest of vital bone marrow from the femur by continuous irrigation and simultaneous aspiration of the irrigation fluid. The irrigation fluid as well as the osseus particles within the irrigation fluid can be harvested using a filter. Actual studies demonstrate that the reaming debris obtained with RIA contains elevated levels of FGF1 , PDGF, IGF-1, TGF- $\beta 1$, and BMP-1 in comparison with samples obtained from the iliac crest using needle puncture/ aspirate technique [55]. Moreover, it was reported recently that human reaming debris is a rich source of multipotent stem cells. The harvested cells exhibit a phenotype and a plasticity commonly attributed to MSC in culture [56]. Own work has shown that in comparison with aspirates obtained from iliac crest RIA aspirates from the femur contained a significantly higher percentage of CD34 + progenitor cells, a significantly higher concentration of MSC and a significantly higher concentration of early EPC. The percentage of late EPC did not differ between both sites. Moreover, the capability of MSC for calcium deposition was significantly enhanced in MSC obtained with RIA [47]. In a subsequently following study, we hypothesized that the harvest procedure influences the osteogenic activity of human MSC rather than the tissue site itself. We generally were able to reproduce that concentration and osteogenic capacity of MSC harvested with RIA is higher compared to MSC from the iliac crest. We observed that the harvest procedure is a critical factor in osteogenesis of MSC in vitro. The altered gene expression and function of femur-derived MSC (RIA) might be due to the harsh isolation procedure [57].

\section{Scaffolds}

Oftentimes, to spatially restrict regenerative cells, cells will be seeded on a carrier before being placed into the bone defect. Different kinds of scaffolds are available which vary in their chemical composition, shape and surface characteristics. Osteoconductivity, osteoinductivity and adherence of cells are dependent on material properties. A great variety of scaffolds belonging to different classes are commercially
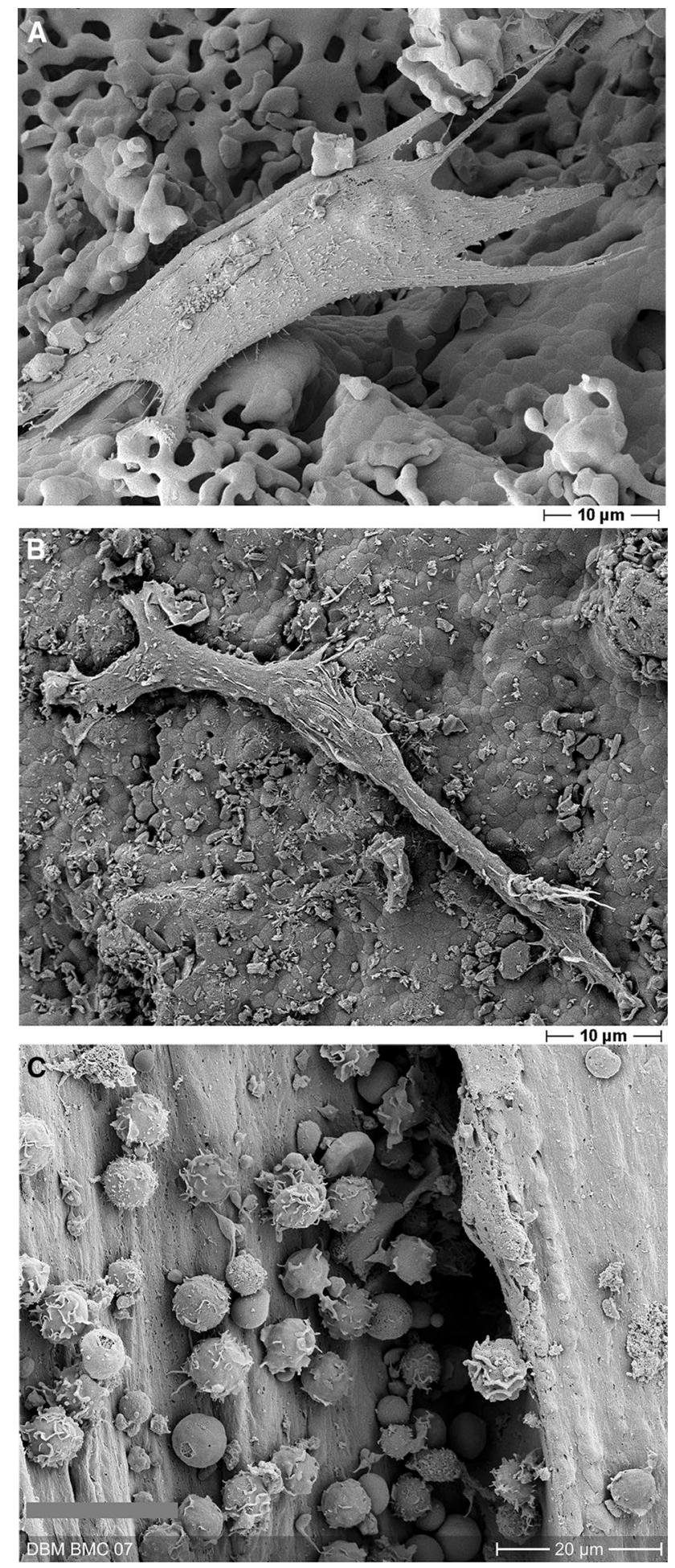

Fig. 2 Cells with regenerative potential used in our research, SEM images. MSC (a), EPC (b) and BMC (c) on various types of scaffold (A: $\beta$-TCP; B: $\beta$-TCP; C: demineralized bone matrix) 2 days after seeding in vitro. Cells were fixed with glutardialdehyde, dehydrated and finally treated with dihydroxydisilazane overnight before being sputtered with gold 
available. Those include synthetic scaffolds based on minerals present in bone such as hydroxyapatite or beta-tricalciumphosphate ( $\beta$-TCP), other synthetic materials are based on derivates of polylactic acid. Non-synthetic scaffolds are frequently based on processed bovine cortical bone and spongiosa, scaffolds based on differentially processed bone obtained from human donors are also available.

Ideal biomaterials for bone reconstruction should fulfill requirements including mechanical stability, osteoinductivity, osteoconductivity and support of revascularization. It is generally accepted that the main aspects of the scaffold's biological impact were pore size, certain surface micro- and nanostructure, stiffness and the release of putatively beneficial ions such as $\mathrm{Ca}^{2+}$. However, currently available single component materials do not meet all these requirements, despite increasing research efforts in this field. Hence, more sophisticated biomaterials are needed and combining different biodegradable biomaterials with complementary properties may circumvent individual shortcomings.

\section{Assessment of scaffold cytocompatibility}

Actually, there is a high demand for cytocompatibility testing, since the effect of the scaffold on cells is not predictable solely based on information about the scaffold's chemical and physical properties. Therefore, we established a panel of assays that allows us to rate the cytocompatibility of a scaffold for BMC, EPC and MSC in a 96-well plate scale. Our test panel includes the assessment of seeding efficacy, metabolic activity, relative number of adhering cells, evaluation of functional aspects such as the secretion of VEGF and expression of genes relevant for vasculogenesis and osteogenesis.

We observed significant differences of cytocompatibility between different sorts of scaffolds, which were consistently found for each cell type that was analyzed. In particular, the relevance of the physical surface characteristics was demonstrated. It was observed that number, metabolic activity and gene expression of MSC, respectively, EPC, differed significantly when seeded on $\beta$-TCP scaffolds being chemically identic but different in their surface topography. Both cell types demonstrated a high adhesion and survival rate on the $\beta$-TCP offering a smooth surface, whereas cell number and cell activity rapidly declined on the rough material $[58,59]$.

Natural materials on the basis of human processed bone material demonstrated a high cytocompatibility for MSC, EPC [58-60] and BMC [49] that was superior to synthetic materials with regard to initial adherence and long-term survival (Fig. 3).

The importance of certain ions being released from the scaffold for the differentiation, survival and activity of EPC was demonstrated using a composite material developed in our department consisting of a PLA carrier combined with up to $40 \%$ bioglass (BG40, $\mathrm{CaO}-\mathrm{SiO}_{2}-\mathrm{SiO}_{2} 80$ mol$\%, \mathrm{CaO} 20$ mol-\%) [61]. BG40 released the most calcium, and improved endothelial differentiation and vitality of EPC best. This effect was mimicked by adding an equivalent amount of calcium to the medium and was diminished in the presence of the calcium chelator, EGTA.

\section{Experimental in vivo transfer studies}

\section{Transplantation of pre-cultivated progenitor cells improves bone healing in vivo}

We also analyzed the portability of the in vitro results to the in vivo situation. The general proceeding of those experiments is shown in Fig. 4.

Keeping our initial hypothesis in mind, that the combination of cells with complement properties is more effective for the bone defect healing compared to approaches using single cell sorts, we evaluated the effect of EPC alone or in combination with mesenchymal stem cells (MSC) on the early vascularization and bone healing in our critical size defect model of the athymic rat.

We were able to show that early vascularization after 1 week was significantly improved in the EPC/MSC group and the EPC group. The formation of a primitive vascular plexus was also detectable in the $\beta$-TCP, MSC, or autologous bone group, but on a significantly higher level, if EPC were transplanted alone or combined with MSC. The degree of early vascularization correlated well with the release of VEGF into the tissue, suggesting a paracrine effect of the transplanted EPC.

Concomitantly, bone defect healing after 8 weeks was most prominent, if MSC and EPC were transplanted into the bone defect compared to all other groups. Those findings indicated a synergistic effect between EPC and MSC and that the initial stage of neovascularization mediated by EPCs is crucial for complete bone healing in the late phase $[62,63]$.

The same positive effect of co-transplanted MSC and EPC on bone healing and vascularization was seen in a rat critically sized calvarian defect model using syngenic MSC and EPC seeded on a newly developed scaffold consisting of polylactic acid reinforced with $40 \%$ bioglass $[61,64]$.

\section{BMC in bone healing: preclinical studies}

Despite their beneficial effects on bone healing, the use of culture expanded cells comes with inherent disadvantages, including regulatory ones. To obtain a sufficient number of cells for clinical use, MSC will require several weeks of expansion in culture, markedly delaying definitive surgical repair of the bone defect. There is some evidence that, during that process, MSC may accumulate genetic alterations, 
Fig. 3 Differential adhesion of EPC on biomaterials. Adhesion of cells is strongly correlated to the surface characteristics of the biomaterial. Despite being chemically identic, cells show tremendously different adhesion on $\beta$-TCP from supplier A compared to the $\beta$-TCP from supplier B. Note the different surface structures of the materials. Natural materials based on processed human bone demonstrate generally a good cytocompatibility

\section{EPC on scaffolds}

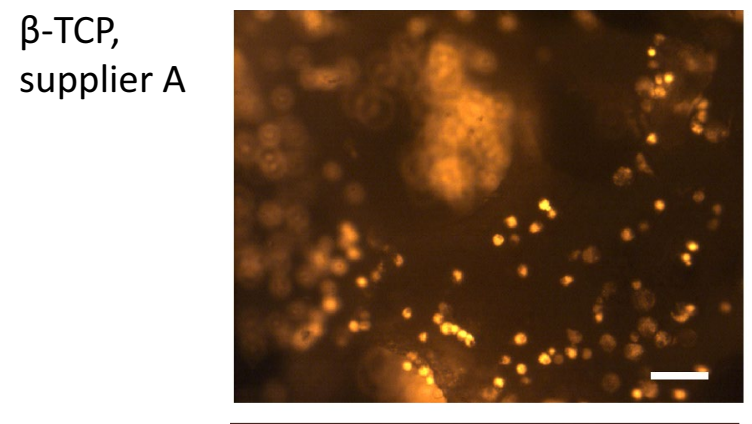

B-TCP,
supplier B

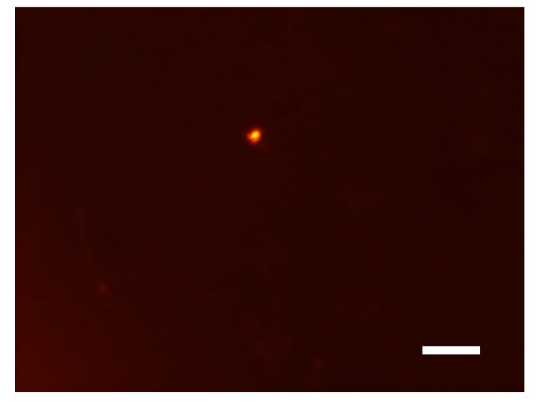

processed

human

spongiosa

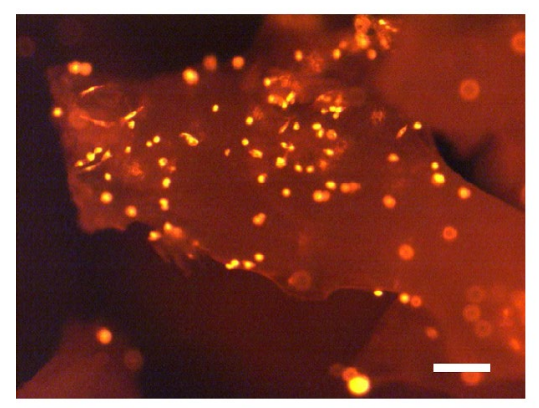

Surface of scaffolds
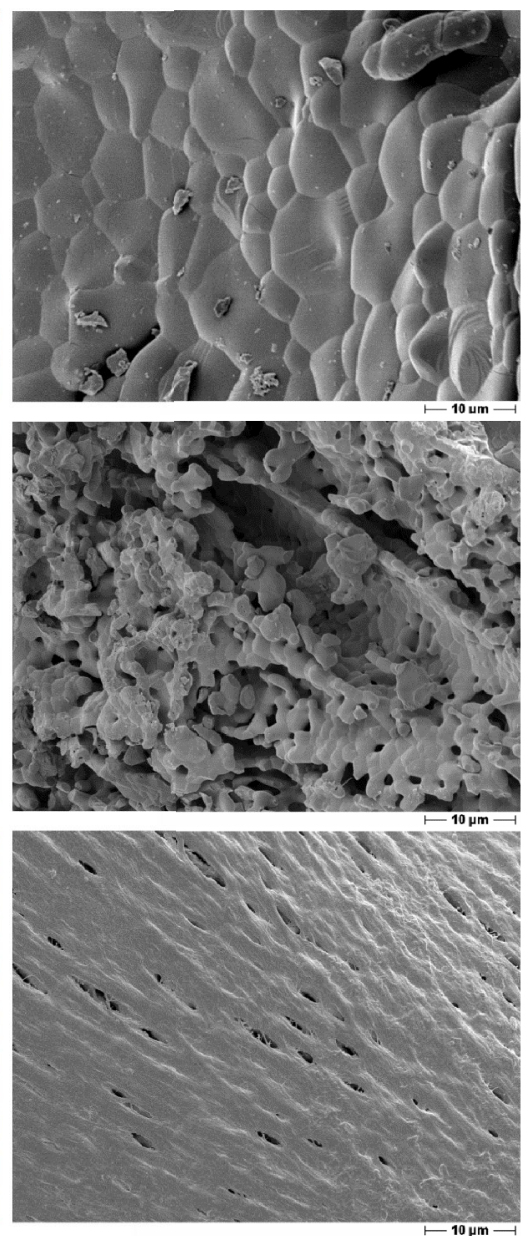

which in turn might increase the risk of cancer [65]. Also, some of the growth factors that are used for EPC differentiation in vitro such as IGF-1 might support transformation of hematopoietic progenitors [66] from which EPC develop [51].

Bone marrow mononuclear cells (BMC) might be a promising alternative to cultured cells, if preliminary data about their osteoinductive properties can be confirmed in humans, specifically also in humans with pathological bone structure. Comparative data regarding the needs of BMC for the adhesion on biomaterials and biocompatibility to various biomaterials are lacking to a large extent. Therefore, we evaluated whether a surface coating would enhance human BMC adhesion and analyze the biocompatibility of three different kinds of biomaterials. $\beta$-TCP, demineralized bone matrix (DBM), and bovine cancellous bone (BS) were assessed. The seeding efficacy of BMC on uncoated biomaterials is generally high, although there are differences between these biomaterials. $\beta$-TCP and DBM were similar and both superior to BS. Those in vitro results could be generally confirmed using our femur defect model of the rat. Superior bone healing responses of the $\beta$-TCP and DBM scaffolds compared to BS were observed suggesting either as suitable materials for spatial restriction of BMC used for regenerative medicine purposes in vivo [49, 67]. Based on those preliminary data, we analyzed the impact of BMC seeded on a $\beta$-TCP scaffold in comparison with combined EPC and MSC using the same scaffold in our femur defect model of the male athymic rat in vivo. We observed less chondrocytes and a significantly more advanced bone formation in the BMC and EPC/MSC group in comparison with the control group ( $\beta$-TCP without cells) after 8 weeks. Concomittantly, biomechanical stability of the defect area was significantly enhanced if BMC and EPC/MSC were implanted compared to control. The degree of new bone formation and biomechanical stability was similar between the BMC and the EPC/MSC group. Furthermore, no tumor formation was found either macroscopically or histologically after 26 weeks of BMC implantation [68]. 


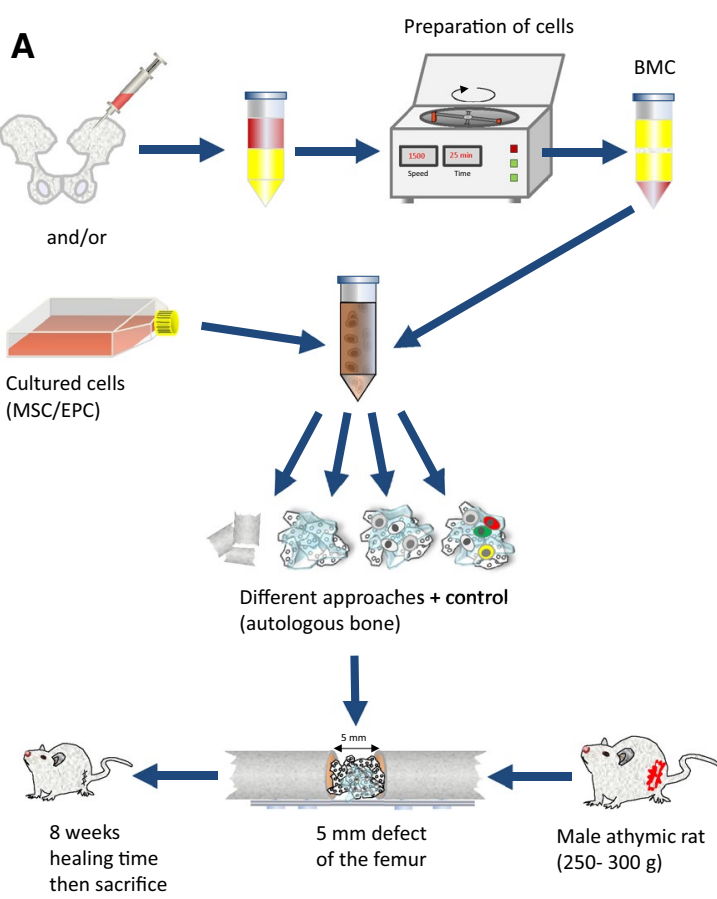

Fig. 4 General scheme of the experimental setup to test various human cell types or scaffolds regarding their effect on bone healing is depicted in (a). The analyses made to evaluate the bone-healing response consist of $\mu \mathrm{CT}$ analysis to evaluate $\mathrm{BMD}$ and architecture of the new formed bone in the defect area, the same samples will be then used to determine the mechanical strength of the defect site using the

\section{BMC in clinical use, phase I and phase lla clinical trials}

Based on our promising preclinical results, we established a cell-based bone regeneration procedure applicable in the whole field of bone defects after trauma, tumors, joint arthroplasty and in osteoporotic defects. We hypothesized that transplantation of BMC $+\beta$-TCP into a bone defect should be safe, feasible and should promote bone formation and bony bridging of the defect resulting in improved clinical outcomes. The clinical problem of these studies is always that in substantial bone defects mostly the defects are very heterogeneous, and additional problems, such as soft tissue defects, or additional injuries exist. To allow for a rather standardized clinical defect situation, we have chosen the situation of a displaced proximal humerus fracture, thus a metaphyseal defect. Such an approach was proposed by Saxer et al. for their studies on adipose-derived stem cells [69].

Protocols for a German Medicines Law GCP trial were prepared and permissions from the local ethics board [No. 350/12] and the federal authority (PEI) [No. 1769] were

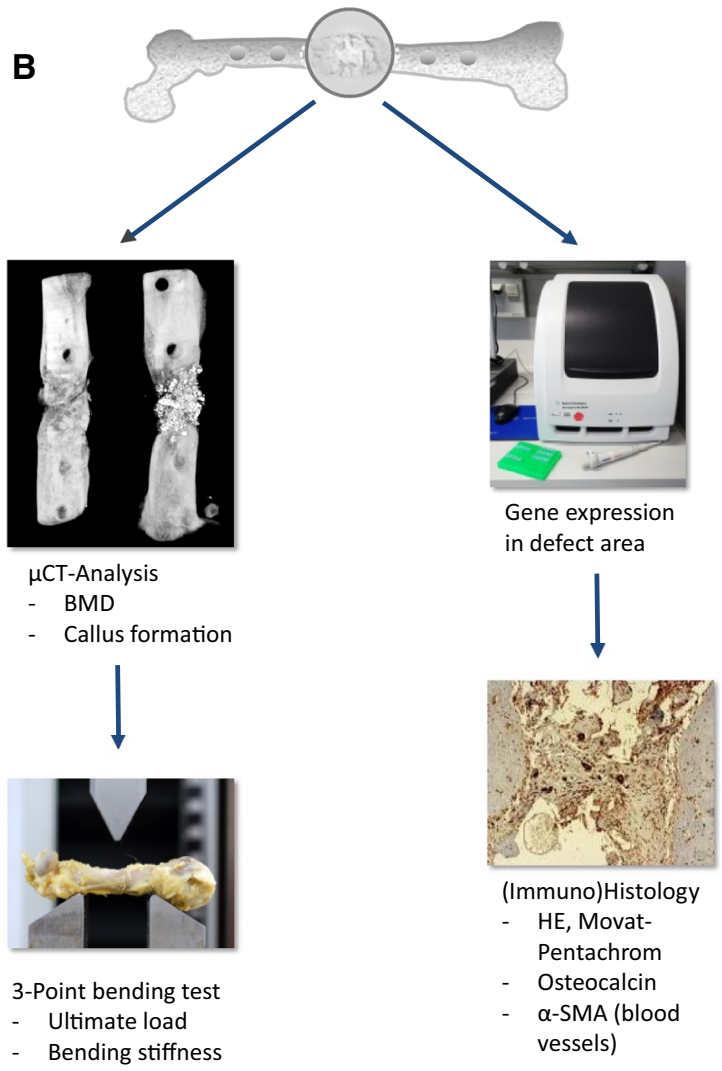

three-point bending test. Additionally, RT-PCR to analyze the expression of genes involved in bone repair is performed using small samples from the defect site. Those bones were subsequently subjected to (immuno) histology to localize structures, cell types and protein expression in the bone defect (b)

obtained for treatment of 10 consecutive, eligible, consenting patients. We generated formal study protocols, including IMPD, and applied for $\S 40 \mathrm{AMG}$ permission from the PEI for this phase I trial (EudraCT-Nr.:2012-004037-17, Date of registration: 30th of August 2012; Date enrolled first participant: 11th of September 2013). A manufacturing license for tissue procurement acc. to $\S 20 \mathrm{~b}$ German Medicines Law and for manufacturing of the advanced therapy medicinal product (ATMP) "BMC2012" acc. to $§ 13$ German Medicines Law, the autologous cell-based study drug, was obtained from the local regulatory agency (Regierungspräsidium Darmstadt). The study was registered in the European Clinical Trial Register as EudraCT No. 2012-004037-17.

After regulatory approval 10 patients were recruited after informed consent and completed follow-up between September 2013 and 2014 and published in 2016 [70].

Criteria for inclusion to this clinical trial were 2-, 3- or 4-fragment fracture (Neer classification), dislocation of $\geq 10 \mathrm{~mm}$ between fragments and/or angle of $\geq 45^{\circ}$ between fragments and/or dislocation of tuberculum major of 
$\geq 5 \mathrm{~mm}$, age $>18$ years, informed consent for surgery and study participation.

The study was a single-arm uncontrolled study. All patients received cell-based therapy with autologous BMC: open reduction and internal fixation (ORIF) of the fracture, augmentation with composite of an acellular bone graft substitute ( $\beta$-TCP) and BMC. Concentration of BMC was $1.3 \times 10^{6} \mathrm{BMC} / \mathrm{ml} \beta$-TCP analogous to the prior animal experiments.

Five follow-up visits for clinical and radiological control up to 12 weeks were performed and neither morbidity at the harvest site nor morbidity at the surgical wound site was observed. Furthermore, neither local nor systemic inflammation was noted. All fractures healed within the observation time without secondary dislocation. We conclude that cell therapy with autologous BMC for bone regeneration appeared to be safe and feasible with no drug-related adverse reactions being described to date. The impression of efficacy was given, although the study was not powered nor controlled to detect such [70].

Therefore, a phase IIa-clinical trial was initiated to evaluate the effect of autologous BMC on bone healing. Formal study protocols for a multicentric, open, randomized phase IIa trial (EudraCT-Nr.:2015-001820-51) were generated and approval of the local ethics board [369/15] was obtained. A total of 94 patients distributed prospectively and randomly in a 1:1 relation to verum (BMC) or control group ( $\beta$-TCP) is estimated and until June 2017, 24 patients have been already enrolled. We expect a study duration of 2-2.5 years and are eager to see if the phase I results can be demonstrated in a prospective randomized trial. The study design is shown in Fig. 5.

\section{Discussion}

Alternative approaches ultimately based on the transplantation of vital bone-derived cells, respectively, bone material within the operative procedure by direct separation were previously evaluated by other groups [71, 72]. But up to date the large majority of patients still receive complete cancelleous bone graft from iliac crest or femur [73], which has the disadvantage of donor-site morbidity and limited material. Other approaches such as the use of nonviable scaffolds [74] cannot demonstrate a sufficient biological activity and guided bone healing. Thus, the advantages of using minimally manipulated cell drugs as opposed to ex vivocultivated stem cells are apparent. These include the risk of transmitting infectious agents with the cells, high laboratory costs and the risk, although probably small, of malignant transformation of long-term cultured cells [63-65].

Other treatment options to bone marrow processing for enrichment of vital progenitor cells have also been taken. Thus, concentrated autologous bone marrow aspirate was implanted together with a scaffold consisting of hydroxyapatite into bone defects and reportedly lead to a significant bone healing in almost all cases [75]. Of note, although clearly fulfilling the criteria of an advanced therapy
Fig. 5 Study design of the BMC IIa-clinical trial (EudraCTNr.:2015-001820-51)

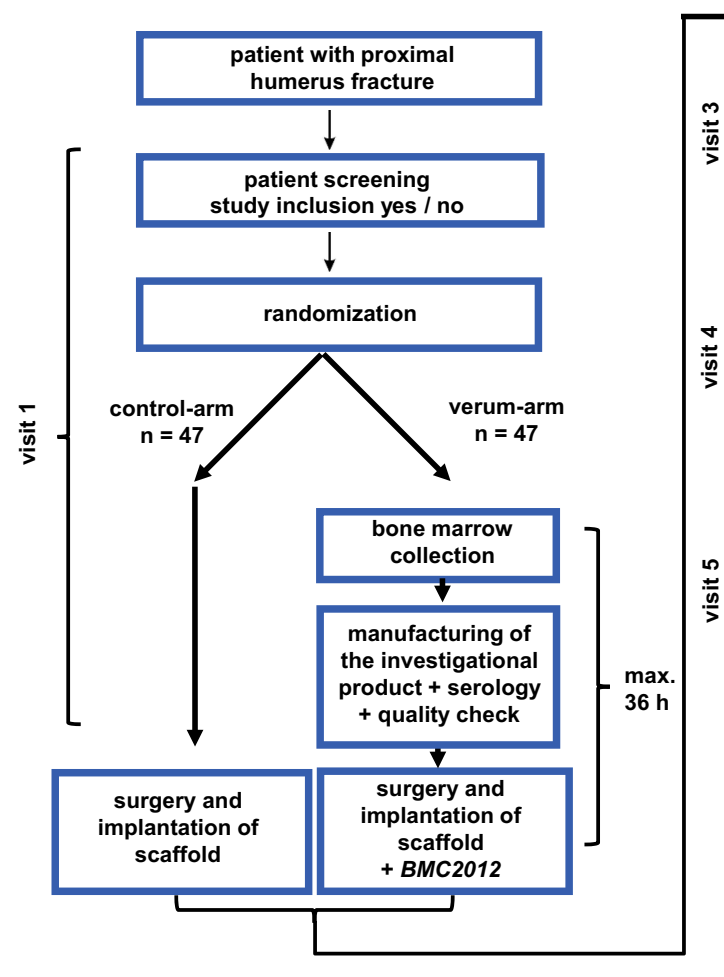


medicinal product (ATMP) and hence requiring a manufacturing authorization and some kind of marketing authorization, these cell products were not regulator-approved at that time.

The metaphyseal fracture model we use in our clinical study was chosen to show a general effect of BMC in bone healing in human. The model is consistent feasible and comparable. In rats, we were able to show that BMC support bone healing in diaphyseal segmental defects. To the effectiveness of BMC in diaphyseal segmental defects in human further models are being developed.

\section{Conclusion and perspective}

Our research history demonstrated the great potential of various stem cell species to support bone defect healing. It was clearly shown that the combination of different cell types is superior to approaches using single cell types. We further demonstrate that it is feasible to translate preclinically developed protocols from in vitro to in vivo experiments and follow positive convincing results into a clinical setting to use autologous stem cells to support bone healing.

With this review, we aimed to demonstrate a possible translational pathway from in vitro over experimental in vivo data to the clinical situation, which is possible in an academic setting. Furthermore, the clinical studies allow again a translation from the clinic to the bench. In particular, we attempt currently to improve the BMC-supported observed bone healing by further studies including optimization of scaffold formulations, evaluation of optimal cell concentrations, improvement of angiogenic and osteogenic properties of BMC by modification of certain $\mu$ RNAs and of the analysis of effective cell populations within BMC. These experiments are performed in parallel with the phase IIa clinical study to improve hopefully possible further research.

Funding The authors would like to thank the LOEWE Center for Cell and Gene Therapy Frankfurt, funded by Hessisches Ministerium für Wissenschaft und Kunst (HMWK; "Hessian Ministry of Higher Education, Research and the Arts"; funding reference number: III L 4-518/17.004 [2010]), the AO (05-S23, S-10-47-H, S-11-64-N) and the German Institute for Cell and Tissue Replacement gGmbH (DIZG, Berlin) for financial assistance of parts of the experimental and clinical studies.

\section{Compliance with ethical standards}

Conflict of interest René Verboket, Maximilian Leiblein, Caroline Seebach, Christoph Nau, Maren Janko, Marlene Bellen, Halvard Bönig, Dirk Henrich and Ingo Marzi declare that they have no conflict of interest.
Ethical approval This article does not contain any studies with human or animal subjects.

Open Access This article is distributed under the terms of the Creative Commons Attribution 4.0 International License (http://creativecommons.org/licenses/by/4.0/), which permits unrestricted use, distribution, and reproduction in any medium, provided you give appropriate credit to the original author(s) and the source, provide a link to the Creative Commons license, and indicate if changes were made.

\section{References}

1. Cattaneo R, Catagni MA, Guerreschi F. Applications of the Ilizarov method in the humerus. Lengthenings and nonunions. Hand Clin. 1993;9:729-39.

2. Weiland AJ. Current concepts review: vascularized free bone transplants. J Bone Jt Surg. 1981;63:166-9.

3. Giannoudis PV, Faour O, Goff T, Kanakaris N, Dimitriou R. Masquelet technique for the treatment of bone defects: tipstricks and future directions. Injury. 2011;42:591-8.

4. Khan Y, Yaszemski MJ, Mikos AG, Laurencin CT. Tissue engineering of bone: material and matrix considerations. J Bone Jt Surg. 2008;90(Suppl 1):36-42.

5. Vacanti J, Langer R, Upton J, Marler J. Transplantation of cells in matrices for tissue regeneration. Adv Drug Deliv Rev. 1998;33:165-82.

6. Jäger M, Hernigou P, Zilkens C, Herten M, Li X, Fischer $\mathrm{J}$, et al. Cell therapy in bone healing disorders. Orthop Rev. 2010;2:20.

7. Jäger M, Jelinek E, Wess K, Scharfstadt A, Jacobson M, Kevy $\mathrm{S}$, et al. Bone marrow concentrate: a novel strategy for bone defect treatment. Curr Stem Cell Res Ther. 2009;4:34-43.

8. Jäger M. Joint-preserving surgery for atraumatic avascular necrosis. Osteologie. 2010;19:29-35.

9. Hendrich C, Engelmaier F, Waertel G, Krebs R, Jäger M. Safety of autologous bone marrow aspiration concentrate transplantation: initial experiences in 101 patients. Orthop Rev. 2009;1:32.

10. Kurkalli BG, Gurevitch O, Sosnik A, Cohn D, Slavin S. Repair of bone defect using bone marrow cells and demineralized bone matrix supplemented with polymeric materials. Curr Stem Cell Res Ther. 2010;5:49-56.

11. Yoshimi R, Yamada Y, Ito K, Nakamura S, Abe A, Nagasaka $\mathrm{T}$, et al. Self-assembling peptide nanofiber scaffolds, platelet-rich plasma, and mesenchymal stem cells for injectable bone regeneration with tissue engineering. J Craniofac Surg. 2009;20:1523-30.

12. Marlovits S, Striessnig G, Kutscha-Lissberg F, Resinger C, Aldrian SM, Vécsei V, et al. Early postoperative adherence of matrix-induced autologous chondrocyte implantation for the treatment of full-thickness cartilage defects of the femoral condyle. Knee Surg Sports Traumatol Arthrosc. 2004;13:451-7.

13. Marlovits S, Zeller P, Singer P, Resinger C, Vécsei V. Cartilage repair: generations of autologous chondrocyte transplantation. Eur J Radiol. 2006;57:24-31.

14. Nöth U, Reichert J, Reppenhagen S, Steinert A, Rackwitz L, Eulert J, et al. Cell based therapy for the treatment of femoral head necrosis. Orthopade. 2007;36:466-71.

15. Jäger $M$, Wild A, Lensing-Höhn S, Krauspe R. Influence of different culture solutions on osteoblastic differentiation in cord blood and bone marrow derived progenitor cells. Biomed Tech (Berl). 2003;48:241-4

16. Turnovcova K, Ruzickova K, Vanecek V, Sykova E, Jendelova P. Properties and growth of human bone marrow mesenchymal 
stromal cells cultivated in different media. Cytotherapy. 2009;11:874-85.

17. Zilkens C, Lögters T, Bittersohl B, Krauspe R, Lensing-Höhn $\mathrm{S}$, Jäger M. Spinning around or stagnation-what do osteoblasts and chondroblasts really like? Eur J Med Res BioMed Cent. 2010;15:35.

18. Dahl J-A, Duggal S, Coulston N, Millar D, Melki J, Shahdadfar A, et al. Genetic and epigenetic instability of human bone marrow mesenchymal stem cells expanded in autologous serum or fetal bovine serum. Int J Dev Biol. 2008;52:1033-42.

19. Siddiqi S, Mills J, Matushansky I. Epigenetic remodeling of chromatin architecture: exploring tumor differentiation therapies in mesenchymal stem cells and sarcomas. Curr Stem Cell Res Ther. 2010;5:63-73.

20. Giannini S, Buda R, Vannini F, Cavallo M, Grigolo B. One-step bone marrow-derived cell transplantation in talar osteochondral lesions. Clin Orthop Relat Res. 2009;467:3307-20.

21. Connolly JF, Guse R, Tiedeman J, Dehne R. Autologous marrow injection as a substitute for operative grafting of tibial nonunions. Clin Orthop Relat Res. 1991;266:259-70.

22. Hernigou PH, Mathieu G, Poignard A, Manicom O, Beaujean F, Rouard H. Percutaneous autologous bone-marrow grafting for nonunions. J Bone Jt Surg. 2006;88:322-7.

23. Hernigou P, Mathieu G, Poignard A, Manicom O, Beaujean F, Rouard H. Percutaneous autologous bone-marrow grafting for nonunions: surgical technique. JBJS Essent Surg Tech. 2006; os-88:322-7.

24. Giannoudis PV, Einhorn TA, Marsh D. Fracture healing: the diamond concept. Injury 2008 ed. 2007;38(Suppl 4):S3-6.

25. Drosse I, Volkmer E, Capanna R, De Biase P, Mutschler W, Schieker M. Tissue engineering for bone defect healing: an update on a multi-component approach. Injury. 2008;39(Suppl 2):S9-20.

26. Schmidmaier G, Wildemann B, Bail H, Lucke M, Fuchs T, Stemberger A, et al. Local application of growth factors (insulin-like growth factor- 1 and transforming growth factor- $\beta 1$ ) from a biodegradable poly(d,l-lactide) coating of osteosynthetic implants accelerates fracture healing in rats. Bone. 2001;28:341-50.

27. Schmidmaier G, Wildemann B, Heeger J, Gäbelein T, Flyvbjerg A, Bail HJ, et al. Improvement of fracture healing by systemic administration of growth hormone and local application of insulin-like growth factor- 1 and transforming growth factor- $\beta 1$. Bone. 2002;31:165-72.

28. Zhang SJ, Zhang H, Wei YJ, Su WJ, Liao ZK, Hou M, et al. Adult endothelial progenitor cells from human peripheral blood maintain monocyte/macrophage function throughout in vitro culture. Cell Res. 2006;16:577-84.

29. Zhang SJ, Zhang H, Hou M, Zheng Z, Zhou J, Su W, et al. Is it possible to obtain "true endothelial progenitor cells" by in vitro culture of bone marrow mononuclear cells? Stem Cells Dev. 2007;16:683-90.

30. Assmus B. Transplantation of progenitor cells and regeneration enhancement in acute myocardial infarction (TOPCARE-AMI). Circulation. 2002;106:3009-17.

31. Crosby JR, Kaminski WE, Schatteman G, Martin PJ, Raines EW, Seifert RA, et al. Endothelial cells of hematopoietic origin make a significant contribution to adult blood vessel formation. Circ Res. 2000;87:728-30.

32. Henrich D, Hahn P, Wahl M, Wilhelm K, Dernbach E, Dimmeler $\mathrm{S}$, et al. Serum derived from multiple trauma patients promotes the differentiation of endothelial progenitor cells in vitro: possible role of transforming growth factor-betal and vascular endothelial growth factor 165. Shock. 2004;21:13-6.

33. Henrich D, Seebach C, Wilhelm K, Marzi I. High dosage of simvastatin reduces TNF-alpha-induced apoptosis of endothelial progenitor cells but fails to prevent apoptosis induced by IL1beta in vitro. J Surg Res. 2007;142:13-9.

34. Henrich D, Zimmer S, Seebach C, Frank J, Barker J, Marzi I. Trauma-activated polymorphonucleated leukocytes damage endothelial progenitor cells: probable role of CD11b/CD18CD54 interaction and release of reactive oxygen species. Shock. 2011;36:216-22.

35. Gehling UM, Ergün S, Schuch G, Schafhausen P, Kilic N, Schäfer $\mathrm{B}$, et al. In vitro differentiation of endothelial cells (EC) from AC133-positive progenitor cells. Eur J Cancer. 1999;35:S103-4.

36. Peichev M, Naiyer AJ, Pereira D, Zhu Z, Lane WJ, Williams M, et al. Expression of VEGFR-2 and AC133 by circulating human $\mathrm{CD} 34(+)$ cells identifies a population of functional endothelial precursors. Blood. 2000;95:952-8.

37. Fuchs S, Hofmann A, Kirkpatrick CJ. Microvessel-like structures from outgrowth endothelial cells from human peripheral blood in 2-dimensional and 3-dimensional co-cultures with osteoblastic lineage cells. Tissue Eng. 2007;13:2577-88.

38. Dimmeler S, Assmus B, Hermann C, Haendeler J, Zeiher AM. Fluid shear stress stimulates phosphorylation of Akt in human endothelial cells: involvement in suppression of apoptosis. Circulation Res. 1998;83:334-41.

39. Vasa M, Fichtlscherer S, Adler K, Aicher A, Martin H, Zeiher $\mathrm{AM}$, et al. Increase in circulating endothelial progenitor cells by statin therapy in patients with stable coronary artery disease. Circulation. 2001;103:2885-90.

40. Powerski MJ, Henrich D, Sander A, Wastl D, Ludwig K, Marzi I. CD133 + CD34 + stem cells are mobilized after musculoskeletal surgery and target endothelium activated by surgical wound fluid. Langenbeck's Arch Surg. 2010;396:379-87.

41. Janusz Powerski M, Henrich D, Wastl D, Sander A, Marzi I. Surgical wound fluid from elderly patients shows a dramatically reduced potential to stimulate in-vitro recruitment and differentiation of endothelial progenitor cells: role of VEGF-165 and TGF- $\beta 1$. Wounds. 2010;22:204-11.

42. Friedenstein AJ, Petrakova KV, Kurolesova AI, Frolova GP. Heterotopic of bone marrow. Analysis of precursor cells for osteogenic and hematopoietic tissues. Transplantation. 1968;6:230-47.

43. Pittenger MF, Mackay AM, Beck SC, Jaiswal RK, Douglas R, Mosca JD, et al. Multilineage potential of adult human mesenchymal stem cells. Science. 1999;284:143-7.

44. Bruder SP, Fink DJ, Caplan AI. Mesenchymal stem cells in bone development, bone repair, and skeletal regeneration therapy. J Cell Biochem. 1994;56:283-94.

45. Seebach C, Henrich D, Tewksbury R, Wilhelm K, Marzi I. Number and proliferative capacity of human mesenchymal stem cells are modulated positively in multiple trauma patients and negatively in atrophic nonunions. Calcif Tissue Int. 2007;80:294-300.

46. Assmus B, Rolf A, Erbs S, Elsässer A, Haberbosch W, Hambrecht $\mathrm{R}$, et al. Clinical outcome 2 years after intracoronary administration of bone marrow-derived progenitor cells in acute myocardial infarction. Circ Heart Fail. 2010;3:89-96.

47. Henrich D, Seebach C, Sterlepper E, Tauchmann C, Marzi I, Frank J. RIA reamings and hip aspirate: a comparative evaluation of osteoprogenitor and endothelial progenitor cells. Injury. 2010;41(Suppl 2):S62-8.

48. Kuçi Z, Kuçi S, Zircher S, Koller S, Schubert R, Bonig H, et al. Mesenchymal stromal cells derived from CD271 + bone marrow mononuclear cells exert potent allosuppressive properties. Cytotherapy. 2011;13:1193-204.

49. Henrich D, Verboket R, Schaible A, Kontradowitz K, Oppermann E, Brune JC, et al. Characterization of bone marrow mononuclear cells on biomaterials for bone tissue engineering in vitro. Biomed Res Int Hindawi. 2015;2015:1-12. 
50. Tormin A, Li O, Brune JC, Walsh S, Schütz B, Ehinger M, et al. CD146 expression on primary nonhematopoietic bone marrow stem cells is correlated with in situ localization. Blood Am Soc Hematol. 2011;117:5067-77.

51. Pearson JD. Endothelial progenitor cells-hype or hope? J Thromb Haemost 2009; 7:255-62.

52. Kuçi S, Kuçi Z, Kreyenberg H, Deak E, Pütsch K, Huenecke S, et al. CD271 antigen defines a subset of multipotent stromal cells with immunosuppressive and lymphohematopoietic engraftmentpromoting properties. Haematol. 2010;95:651-9.

53. Cuthbert R, Boxall SA, Tan HB, Giannoudis PV, McGonagle D, Jones E. Single-platform quality control assay to quantify multipotential stromal cells in bone marrow aspirates prior to bulk manufacture or direct therapeutic use. Cytotherapy. 2012;14:431-40.

54. Jeon O, Song SJ, Bhang SH, Choi C-Y, Kim MJ, Kim B-S. Additive effect of endothelial progenitor cell mobilization and bone marrow mononuclear cell transplantation on angiogenesis in mouse ischemic limbs. J Biomed Sci. 2007;14:323-30.

55. Schmidmaier G, Herrmann S, Green J, Weber T, Scharfenberger A, Haas NP, et al. Quantitative assessment of growth factors in reaming aspirate, iliac crest, and platelet preparation. Bone. 2006;39:1156-63.

56. Wenisch S, Trinkaus K, Hild A, Hose D, Herde K, Heiss C, et al. Human reaming debris: a source of multipotent stem cells. Bone. 2005;36:74-83.

57. Henrich D, Nau C, Kraft S, Zollfrank M, Kontradowitz K, Oppermann E, et al. Effect of the harvest procedure and tissue site on the osteogenic function of and gene expression in human mesenchymal stem cells. Int J Mol Med. 2016;37:976-88

58. Seebach C, Schultheiss J, Wilhelm K, Frank J, Henrich D. Comparison of six bone-graft substitutes regarding to cell seeding efficiency, metabolism and growth behaviour of human mesenchymal stem cells (MSC) in vitro. Injury. 2010;41:731-8.

59. Schultheiss J, Seebach C, Henrich D, Wilhelm K, Barker JH, Frank J. Mesenchymal stem cell (MSC) and endothelial progenitor cell (EPC) growth and adhesion in six different bone graft substitutes. Eur J Trauma Emerg Surg. 2011;37:635-44.

60. Henrich D, Wilhelm K, Warzecha J, Frank J, Barker J, Marzi I, et al. Human endothelial-like differentiated precursor cells maintain their endothelial characteristics when cocultured with mesenchymal stem cell and seeded onto human cancellous bone. Mediat Inflamm Hindawi. 2013;2013:364591-12.

61. Eldesoqi K, Seebach C, Nguyen Ngoc C, Meier S, Nau C, Schaible A, et al. High calcium bioglass enhances differentiation and survival of endothelial progenitor cells, inducing early vascularization in critical size bone defects. Bhattacharya S, editor. PLoS One. 2013;8:e79058.

62. Seebach C, Henrich D, Kahling C, Wilhelm K, Tami AE, Alini $\mathrm{M}$, et al. Endothelial progenitor cells and mesenchymal stem cells seeded onto beta-TCP granules enhance early vascularization and bone healing in a critical-sized bone defect in rats. Tissue Eng Part A. 2010;16:1961-70.

63. Seebach C, Henrich D, Wilhelm K, Barker JH, Marzi I. Endothelial progenitor cells improve directly and indirectly early vascularization of mesenchymal stem cell-driven bone regeneration in a critical bone defect in rats. Cell Transpl. 2012;21:1667-77.

64. Eldesoqi K, Henrich D, El-Kady AM, Sweify KM, Relja B, Elhady B. Improved bone formation by differentiated mesenchymal stem cells and endothelial progenitor cells seeded on high concentrated bioglass-polylactic acid composite in calvarial rat bone defect. J Stem Cell Res Dev Ther. 2015;2:1-7.

65. Wang Y, Han Z-B, Song Y-P, Han ZC. Safety of mesenchymal stem cells for clinical application. Stem Cells Int Hindawi. 2012;2012:1-4.
66. Jenkins CR, Shevchuk OO, Giambra V, Lam SH, Carboni JM, Gottardis MM, et al. IGF signaling contributes to malignant transformation of hematopoietic progenitors by the MLL-AF9 oncoprotein. Exp Hematol. 2012;40:715-6.

67. Janko M, Sahm J, Schaible A, Brune JC, Bellen M, Schröder K, et al. Comparison of three different types of scaffolds preseeded with human bone marrow mononuclear cells on the bone healing in a femoral critical size defect model of the athymic rat. J Tissue Eng Regen Med. 2017. https://doi.org/10.1002/term.2484. ISSN 1932-7005.

68. Seebach C, Henrich D, Schaible A, Relja B, Jugold M, Bonig $\mathrm{H}$, et al. Cell-based therapy by implanted human bone marrowderived mononuclear cells improved bone healing of large bone defects in rats. Tissue Eng Part A. 2015;21:1565-78.

69. Saxer F, Scherberich A, Todorov A, Studer P, Miot S, Schreiner $\mathrm{S}$, et al. Implantation of stromal vascular fraction progenitors at bone fracture sites: from a rat model to a first-in-man study. Stem Cells. 2016;34:2956-66.

70. Seebach C, Henrich D, Meier S, Nau C, Bonig H, Marzi I. Safety and feasibility of cell-based therapy of autologous bone marrowderived mononuclear cells in plate-stabilized proximal humeral fractures in humans. J Transl Med BioMed Central. 2016;14:314.

71. Ardjomandi N, Duttenhoefer F, Xavier S, Oshima T, Kuenz A, Sauerbier S. In vivo comparison of hard tissue regeneration with ovine mesenchymal stem cells processed with either the FICOLL method or the BMAC method. J Craniomaxillofac Surg. 2015;43:1177-83.

72. Duttenhoefer F, Hieber SF, Stricker A, Schmelzeisen R, Gutwald $\mathrm{R}$, Sauerbier S. Follow-up of implant survival comparing ficoll and bone marrow aspirate concentrate methods for hard tissue regeneration with mesenchymal stem cells in humans. BioRes Open Access. 2014;3:75-6.

73. Dimitriou R, Mataliotakis GI, Angoules AG, Kanakaris NK, Giannoudis PV. Complications following autologous bone graft harvesting from the iliac crest and using the RIA: a systematic review. Injury. 2011;42:S3-15.

74. Carini F, Longoni S, Amosso E, Paleari J, Carini S, Porcaro G. Bone augmentation with TiMesh. autologous bone versus autologous bone and bone substitutes. A systematic review. Ann Stomatol (Roma). 2014;5:27-36.

75. Jäger M, Herten M, Fochtmann U, Fischer J, Hernigou P, Zilkens $\mathrm{C}$, et al. Bridging the gap: bone marrow aspiration concentrate reduces autologous bone grafting in osseous defects. J Orthop Res. 2011;29:173-80.

76. Lokiec F, Ezra E, Khermosh O, Wientroub S. Simple bone cysts treated by percutaneous autologous marrow grafting. A preliminary report. J Bone Jt Surg Br. 1996;78:934-7.

77. Köse N, Gokturk E, Turgut A, et al. Percutaneous autologous bone marrow grafting for simple bone cysts. Bull Hosp Jt Dis. 1999;58:105-10.

78. Hernigou P, Beaujean F. Treatment of osteonecrosis with autologous bone marrow grafting. Clin Orthop Relat Res. $2002 ; 405: 14-23$

79. Rougraff BT, Kling TJ. Treatment of active unicameral bone cysts with percutaneous injection of demineralized bone matrix and autogenous bone marrow. J Bone Jt Surg Am. 2004;84-A:921-9.

80. Chang $\mathrm{CH}$, Stanton RP, Glutting J. Unicameral bone cysts treated by injection of bone marrow or methylprednisolone. J Bone $\mathrm{Jt}$ Surg Br. 2002;84:407-12.

81. Price CT, Connolly JF, Carantzas AC, Ilyas I. Comparison of bone grafts for posterior spinal fusion in adolescent idiopathic scoliosis. Spine (Phila Pa 1976). 2003;28:793-8.

82. Docquier PL, Delloye C. Treatment of simple bone cysts with aspiration and a single bone marrow injection. J Pediatr Orthop. 2003;23:766-73. 
83. Gangji V, Hauzeur JP, Matos C, et al. Treatment of osteonecrosis of the femoral head with implantation of autologous bone-marrow cells. A pilot study. J Bone Jt Surg Am. 2004;86-A:1153-60.

84. Hernigou PH, Poignard A, Beaujean F, Rouard H. Percutaneous autologous bone-marrow grafting for nonunions: influence of the number and concentration of progenitor cells. J Bone Jt Surg A. 2005;87(7):1430-7.

85. Kanellopoulos AD, Yiannakopoulos CK, Soucacos PN. Percutaneous reaming of simple bone cysts in children followed by injection of demineralized bone matrix and autologous bone marrow. J Pediatr Orthop. 2005;25:671-5.

86. Neen D, Noyes D, Shaw M, et al. Healos and bone marrow aspirate used for lumbar spine fusion: a case controlled study comparing healos with autograft. Spine (Phila Pa 1976). 2006;31:E636-E40.

87. Yan ZQ, Chen YS, Li WJ, et al. Treatment of osteonecrosis of the femoral head by percutaneous decompression and autologous bone marrow mononuclear cell infusion. Chin J Traumatol. 2006;9:3-7.

88. Deng G, Ling Q, Li T. Treatment of bone cyst by transplantation of autologous bone marrow combined with allograft bone. Zhongguo Xiu Fu Chong Jian Wai Ke Za Zhi. 2007;21:801-3.

89. Cho HS, Oh JH, Kim HS, et al. Unicameral bone cysts: a comparison of injection of steroid and grafting with autologous bone marrow. J Bone Jt Surg Br. 2007;89:222-6.

90. Wright JG, Yandow S, Donaldson S, et al. A randomized clinical trial comparing intralesional bone marrow and steroid injections for simple bone cysts. J Bone Jt Surg Am. 2008;90:722-30.

91. Park IH, Micic ID, Jeon IH. A study of 23 unicameral bone cysts of the calcaneus: open chip allogeneic bone graft versus percutaneous injection of bone powder with autogenous bone marrow. Foot Ankle Int. 2008;29:164-70.

92. Gan Y, Dai K, Zhang P, et al. The clinical use of enriched bone marrow stem cells combined with porous beta-tricalcium phosphate in posterior spinal fusion. Biomaterials. 2008;29:3973-82.

93. Zamzam MM, Abak AA, Bakarman KA, et al. Efficacy of aspiration and autogenous bone marrow injection in the treatment of simple bone cysts. Int Orthop. 2009;33:1353-8.

94. Sir M, Prochazka V, Gumulec J, et al. Our first experiences with autologous transplantation of bone marrow stem cells to treat pseudarthrosis, delayed fracture healing and long bone defects fracture. Vnitr Lek. 2009;55:187-9.
95. Kitoh H, Kawasumi M, Kaneko H, Ishiguro N. Differential effects of culture-expanded bone marrow cells on the regeneration of bone between the femoral and the tibial lengthenings. $\mathrm{J}$ Pediatr Orthop. 2009;29:643-9.

96. Hernigou P, Poignard A, Zilber S, Rouard H. Cell therapy of hip osteonecrosis with autologous bone marrow grafting. Indian $\mathbf{J}$ Orthop. 2009;43:40-5.

97. Wang BL, Sun W, Shi ZC, et al. Treatment of nontraumatic osteonecrosis of the femoral head with the implantation of core decompression and concentrated autologous bone marrow containing mononu-clear cells. Arch Orthop Trauma Surg. 2010;130:859-65.

98. Miller MA, Ivkovic A, Porter R, et al. Autologous bone grafting on steroids: preliminary clinical results. A novel treatment for nonunions and segmental bone defects. Int Orthop. 2010;35:599-605

99. Yamasaki T, Yasunaga Y, Ishikawa M, et al. Bone-marrowderived mononuclear cells with a porous hydroxyapatite scaffold for the treatment of osteonecrosis of the femoral head: a preliminary study. J Bone Jt Surg Br. 2010;92:337-41.

100. Gessmann J, Köller M, Godry H, Schildhauer TA, Seybold D. Regenerate augmentation with bone marrow concentrate after traumatic bone loss. Orthop Rev (Pavia) 2012;4(1):e14. (Epub 2012 Mar 27).

101. Kassem MS. Percutaneous autogenous bone marrow injection for delayed union or non union of fractures after internal fixation. Acta Orthop Belg. 2013;79:711-7.

102. Lee DH, Ryu KJ, Kim JW, Kang KC, Choi YR. Bone marrow aspirate concentrate and platelet-rich plasma enhanced bone healing in distraction osteogenesis of the tibia. Clin Orthop Relat Res. 2014;472:3789-97.

103. Desai P, Hasan SM, Zambrana L, Hegde V, Saleh A, Cohn MR. Lane JM Bone mesenchymal stem cells with growth factors successfully treat nonunions and delayed unions. HSS J. 2015;11(2):104-11.

104. Hernigou P, Guissou I, Homma Y, Poignard A, Chevallier N, Rouard H, et al. Percutaneous injection of bone marrow mesenchymal stem cells for ankle non-unions decreases complications in patients with diabetes. Int Orthop. 2015;39:1639-43. 